\title{
Toxicity on Class of Antibiotic Agents Using Toxtree Software and Its Interaction with Its Receptors Using Molecular Virtual Docker Software
}

\author{
Sovia Aprina Basuki*, Neva Melinda Maulanasari and Engrid Juni Astuti \\ Department of Pharmacy, Faculty of Health Science, University of Muhammadiyah Malang, \\ Indonesia \\ Jalan Bendungan Sutami 188A, Kota Malang, Jawa Timur, 65145 \\ *Corresponding author: soviaaprina@gmail.com
}

\begin{abstract}
Background Antibiotics is a drug used to treat infections caused by bacteria that are often used in the practice of pharmacy. In addition to the therapeutic effect of antibiotics also have side effects. The most common side effects of diarrhea, but it also can cause serious effects if there are toxicophore groups in the antibiotic drug. Objective: So the purpose of this study was to determine the drug class of antibiotics that are carcinogenic and mutagenic along with the group predicted to cause potential carcinogenic and mutagenic characteristics are based Toxtree, then know interaction group of carcinogenic and mutagenic antibiotics with receptor based MVD. Method: used in silico that is antibiotic drug toxicity predicted with Toxtree and their interaction with the receptor is predicted with MVD. the result form this study that is from 131 antibiotic drug tested, there were 65 drug detected has a cluster of potentially carcinogenic and mutagenic. Then analysis related to the type of group causes carcinogenic and mutagenic showed that there were 10 toxicophor group with genotoxic mechanism and 4 toxicophor group with non-genotoxic mechanism. Result: After testing the docking of 65 drugs there were 36 drug with their toxicophore group including farmacophore group that bind to amino acid receptors that kind of bond hydrogen bonds. Conclusion: of this study are 36 antibiotics potentially carcinogenic and mutagenic characteristics on the human body.
\end{abstract}

Keyword : Antibiotic, Carcinogenicity, Mutagenicity, Toxtree, Molegro Virtual Docker

\section{INTRODUCTION}

Antibiotics are drugs used to treat infections caused by bacteria. However, antibiotics also have side effects which is varied depend on antibiotic, its dose, and individual condition as well. The most common side effect is diarrhea, but it can be possible causing serious effects notably the compound which contain toxicophore groups. A toxicophore is a chemical structure or a portion of a structure (e.g., a functional group) that is related to the toxic properties of a chemical.

This research will be conducted toxicity tests on antibiotic compounds. Toxicity test consists of 3 types of in silico, in vitro, and in vivo. All three methods have advantages and disadvantages of each, but all three can be mutually supportive. the test of carcinogenic and mutagenic toxicity in vitro is used methods Cell Transformation Assays (CTA) and Gap Junction intercellular Communication (GJIC) (Eisenbrand, 2002). In vivo test is appliedlong-term rodent carcinogenicity bioassays method which is usually for two years (Fielden and Kolaja, 2008). Whereas the carcinogenic and mutagenic toxicity tests in silico utilize predictive models over the computationally. The purpose of predictive in 
silico including as a preliminary test, for screening test compounds that many before proceed to the stage of in vitro and in vivo, for predicting the toxicity of a compound, and in case compoundswhich are not posible to be studied using in vitro and in vivo methods (Ekins et al., 2007).

The purpose of this research was to know carcinocity and mutagenicity of antibiotics along predicted groups which is responsible to these toxicities based on Toxtree. Those functional groups were called toxicophores. Further those toxicophores were observed their interaction with its each protein targets using Molegro Virtual Docker software.

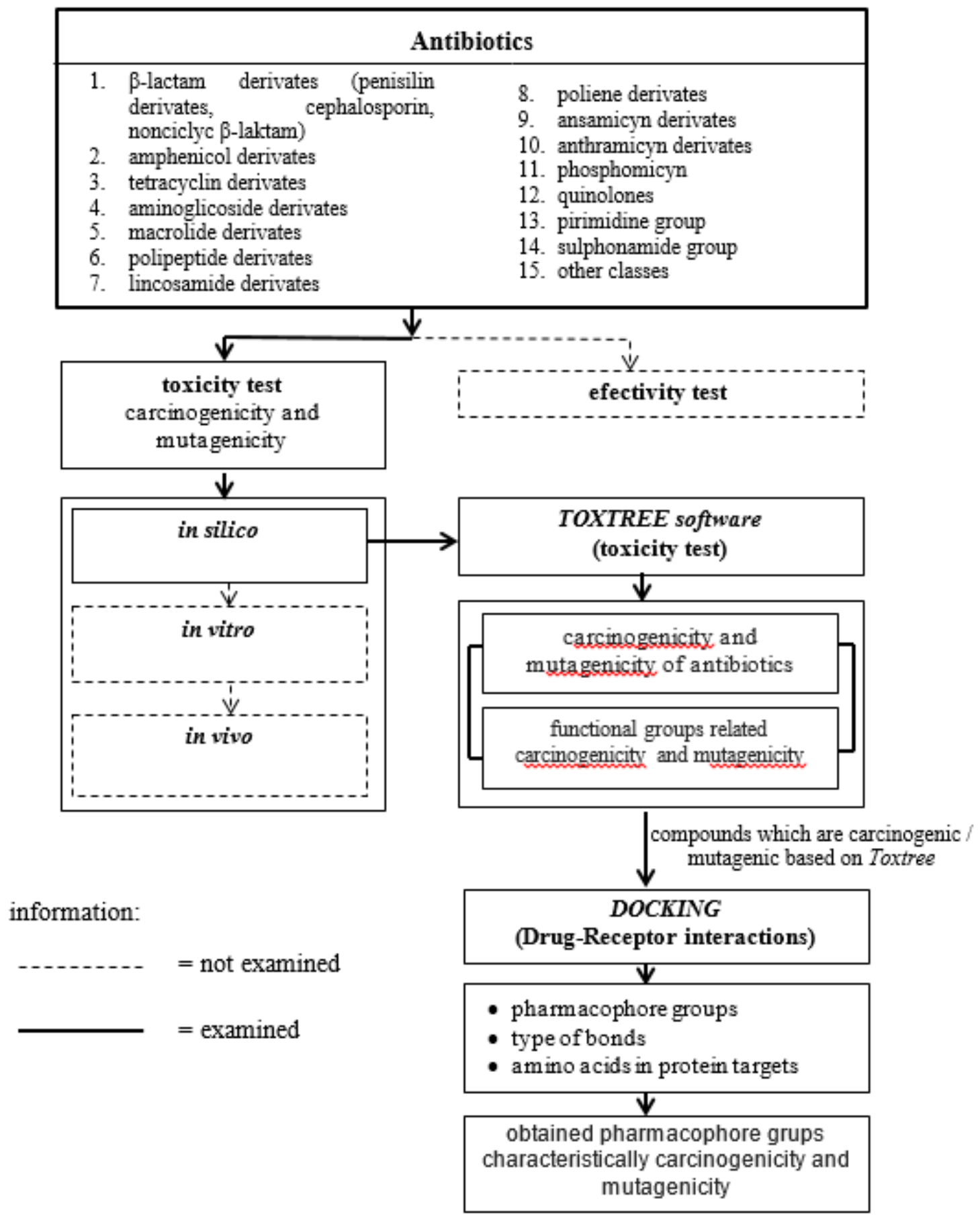




\section{METHOD}

Softwareswere used in this study were:

1. Toxtree v2.6.13

Toxtree is a software developed by Ideaconsult Ltd. (Sofia, Bulgaria) under the terms of the contract JRC. The software is freely accessible as a service for scientific researchers and anyone with an interest in the application of computer-based estimation methods in the assessment of chemical toxicity (Toxtree, 2015)

2. Molegro Virtual Docker v5.0

Molegro Virtual Docker v5.0 is a major tool in structural molecular biology with the aid of computer models to predict the ligand binding to the target protein region in 3D structure. Docking in this study is used to rapidly and flexibly to study and predict the orientation and binding affinity of antibiotics by using Molegro Virtual Docker (Molegro, 2011).

3. ChemDraw

ChemDraw is one of the application program Ultra Chem Office 2010 v12, for drawing 2D and 3D structures in the fields of chemistry, especially organic chemistry, biochemistry, and polymers. In this study ChemDraw used to support SMILES Toxtree in providing data and the method of docking with the software Molegro Virtual Docker is used to draw the structure of 2D, 3D, optimize energy, and save the file in the form of SYBYL MOL2 (SYBYL2).

4. PubChem

PubChem is designed to provide information about the biological activities of small molecules, generally those with a molecular weight of less than 500 dalton. Merging PubChem with NCBI Entrez retrieval system provides sub / structures, structures with similarities, bioactivity of data as well as links to information in the biological properties and Sources Protein PubMed NCBI 3D structure. In this study PubChem used to support Toxtree in providing data SMILES.

5. PDB (Protein Data Bank)

Protein Data Bank is the only provision of storing information in the form of 3D structures of proteins, nucleic acids, and complex structures RCSB GDP can be accessed at http://sg.pdb.org. In this study, the GDP is used to support the method of docking with the software Molegro Virtual Docker in providing data PDB ID.

\section{RESULT AND DISCUSSION}

In this study conducted toxicity tests on 131 antibiotic compounds. Toxicity tests with the software Toxtree v.2.6.13 by using two methods: carcinogenicity (genotoxic and mutagenicity) rule-based ISS and mutagenicity in vitro by the rules of the ISS. Thereafter, compounds which were carcinogenic or mutagenic based Toxtree was docked using Virtual Docker Molegro v.5.0software. These software was aimed to determine antibiotic drug interactions with receptors based on several points, such as farmakofor groups, amino acids in the receptors, and type of bonds. Before docking testing, internal validations were first done. Parameters of internal validation is the value of RMSD $<2.0$ (table 1). 
Table 1 The recapitulation of antibiotic compounds were toxic and farmakofor

\begin{tabular}{llccc}
\hline No & Antibiotics & $\begin{array}{c}\text { Total } \\
\text { Antibiotics } \\
\text { (Compounds) }\end{array}$ & $\begin{array}{c}\text { Antibiotics Contained } \\
\text { Toxicophores } \\
\text { (Compounds) }\end{array}$ & $\begin{array}{c}\text { Pharmacophores Contained } \\
\text { Toxicophores (Compounds) }\end{array}$ \\
\hline $\mathbf{1}$ & ק-lactam & 53 & 17 & 13 \\
$\mathbf{2}$ & amphenicol & 4 & 4 & - \\
$\mathbf{3}$ & tetracyclin & 10 & 10 & 10 \\
$\mathbf{4}$ & aminoglikoside & 13 & - & - \\
$\mathbf{5}$ & makrolide & 7 & 2 & - \\
$\mathbf{6}$ & polipeptide & 4 & - & - \\
$\mathbf{7}$ & linkosamide & 5 & 2 & - \\
$\mathbf{8}$ & poliene & 3 & 1 & - \\
$\mathbf{9}$ & ansamycin & 1 & 1 & 2 \\
$\mathbf{1 0}$ & anthracyclin & 4 & 3 & 1 \\
$\mathbf{1 1}$ & phosphomycin & 4 & 1 & 1 \\
$\mathbf{1 2}$ & quinolone & 13 & 13 & - \\
$\mathbf{1 3}$ & pirimidine & 1 & 1 & 5 \\
$\mathbf{1 4}$ & sulphonamide & 6 & 6 & 3 \\
$\mathbf{1 5}$ & other classes & 6 & 5 & \\
\hline
\end{tabular}

The results showed that from 131 tested antibiotics compounds, there were 65 drugs detected had potential carcinogenic and mutagenic effect. Then those 65 compounds were analyzed the type of bonds which caused carcinogenic and mutagenic using MDV showed that there were 10 toxicophore groups with genotoxic mechanism and 4 toxicophore groups with nongenotoksik mechanism. Besides, 36 toxicophores were contained in pharmacophores via hydrogen bonds (table 2).

Table 2 Docking Analysis Results Using Software Virtual Docker Molegro

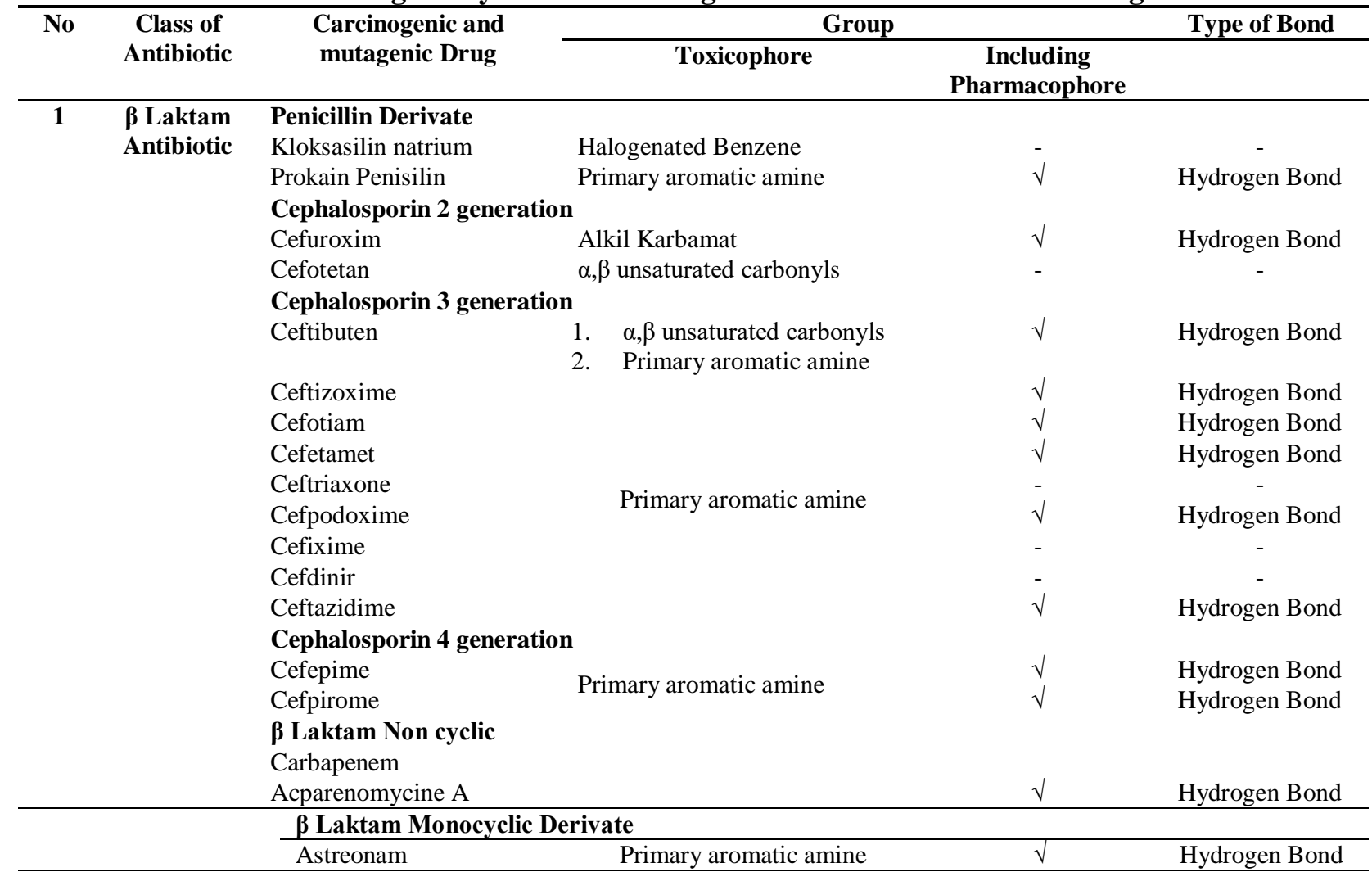


Table 2 Docking Analysis Results Using Software Virtual Docker Molegro (continued)

\begin{tabular}{|c|c|c|c|c|c|}
\hline \multirow[t]{6}{*}{2} & \multirow{6}{*}{$\begin{array}{c}\text { Amphenicol } \\
\text { Derivate }\end{array}$} & \multirow[t]{2}{*}{ Azidamphenicol } & 1. Azide group & \multirow[t]{2}{*}{-} & \multirow[t]{2}{*}{-} \\
\hline & & & 2. Nitro Aromatic & & \\
\hline & & Cloramphenicol & 1. Aliphatic Halogen & - & - \\
\hline & & & 2. Nitro aromatic & & \\
\hline & & Cetophenicol & Aliphatic halogen & - & - \\
\hline & & Tiamphenicol & & - & - \\
\hline \multirow[t]{10}{*}{3} & \multirow{10}{*}{$\begin{array}{c}\text { Tetracyclin } \\
\text { Derivate }\end{array}$} & Tetracyclin & & $\sqrt{ }$ & Hydrogen Bond \\
\hline & & Oxitetracyclin & & $\sqrt{ }$ & Hydrogen Bond \\
\hline & & Clortetracyclin & & $\sqrt{ }$ & Hydrogen Bond \\
\hline & & Demeclocyclin $\mathrm{HCl}$ & $\alpha, \beta$ unsaturated carbonyls & $\sqrt{ }$ & Hydrogen Bond \\
\hline & & Doxicyclin & & $\sqrt{ }$ & Hydrogen Bond \\
\hline & & Tetracyclin $\mathrm{HCl}$ & & $\sqrt{ }$ & Hydrogen Bond \\
\hline & & Doxicyclin $\mathrm{HCl}$ & & $\sqrt{ }$ & Hydrogen Bond \\
\hline & & Minocyclin & & $\sqrt{ }$ & Hydrogen Bond \\
\hline & & Minocyclin $\mathrm{HCl}$ & 1. $\quad \alpha, \beta$ unsaturated carbonyls & $\sqrt{ }$ & Hydrogen Bond \\
\hline & & Tigecyclin & 2. ethyl aromatic amine & $\sqrt{ }$ & Hydrogen Bond \\
\hline 4 & $\begin{array}{l}\text { Macrolida } \\
\text { Derivate }\end{array}$ & Oleandomicin & Epoxide & - & - \\
\hline \multirow[t]{2}{*}{5} & \multirow{2}{*}{$\begin{array}{c}\text { Lincosamide } \\
\text { Derivate }\end{array}$} & Clindamycin $\mathrm{HCl}$ & \multirow[t]{2}{*}{ Aliphatic Halogen } & - & - \\
\hline & & Clindamycin & & - & - \\
\hline \multirow[t]{4}{*}{6} & \multirow{4}{*}{$\begin{array}{l}\text { Ansamicin } \\
\text { Derivate }\end{array}$} & Rifampicin & \multirow{4}{*}{$\begin{array}{ll}\text { 1. } & \begin{array}{l}\text { Hydrazine } \\
\text { 2. }\end{array} \\
& \begin{array}{l}\text { Subtituted n- } \\
\text { alkylcarboxylic acid (non } \\
\text { genotoxic mecanism) }\end{array} \\
\text { 3. } & \alpha, \beta \text { unsaturated carbonyls }\end{array}$} & $\sqrt{ }$ & Hydrogen Bond \\
\hline & & & & & \\
\hline & & & & & \\
\hline & & & & & \\
\hline \multirow[t]{3}{*}{7} & \multirow{3}{*}{$\begin{array}{c}\text { Antracyclin } \\
\text { Derivate }\end{array}$} & Daunorubicine $\mathrm{HCl}$ & Quinones & - & - \\
\hline & & Doxorubicine $\mathrm{HCl}$ & 1. Quinones & $\sqrt{ }$ & Hydrogen Bond \\
\hline & & Epirubicine & 2. Anthrone & $\sqrt{ }$ & Hydrogen Bond \\
\hline 8 & & sfomycin & Epoxides & $\sqrt{ }$ & Hidrogen Bond \\
\hline 9 & Quinolones & Ciprofloxacin & & $\sqrt{ }$ & Hydrogen Bond \\
\hline & & Norfloxacin & & - & - \\
\hline & & Gemifloxacin & & - & - \\
\hline & & Levofloxacin & & - & - \\
\hline & & Gatifloxacin & & - & - \\
\hline & & Ofloxasin & & - & - \\
\hline & & Moxifloxacin & & - & - \\
\hline & & Ciprofloxacin $\mathrm{HCl}$ & $\alpha, \beta$ unsaturated carbonyls & - & - \\
\hline & & $\begin{array}{l}\text { Levofloxacin } \\
\text { hemihydrate }\end{array}$ & & - & - \\
\hline & & Perfloxacin mesilat & & - & - \\
\hline & & $\begin{array}{l}\text { dihidrat } \\
\text { Grepafloxacin }\end{array}$ & & _ & _- \\
\hline & & Trovafloxacin & & _ & - \\
\hline & & Sparfloxacin & & _ & - \\
\hline 10 & Drunimidim & Trimethonrim & Primary aromatic amine & & \\
\hline & Pyrimıdıne & Irimethoprim & Primary aromatic amıne & - & - \\
\hline 11 & Sulfonamide & Sulfasitin & & $\sqrt{ }$ & Hydrogen Bond \\
\hline & & Sulfisoksazole & & $\sqrt{ }$ & Hydrogen Bond \\
\hline & & Sulfadiazine & 2. Benzensulfonat ether & $\sqrt{ }$ & Hydrogen Bond \\
\hline & & Sulfamethoksazole & (mechanism nongenotoxic) & $\sqrt{ }$ & Hydrogen Bond \\
\hline & & Sulfapiridin & & $\sqrt{ }$ & Hydrogen Bond \\
\hline & & Sulfadoxine & & - & - \\
\hline 12 & Others & Co-trimoksazole & 1. Primary aromatic amine & $\sqrt{ }$ & Hydrogen Bond \\
\hline & & & $\begin{array}{l}\text { 2. Benzensulfonat ether } \\
\text { (mechanism of nongenotoxic) }\end{array}$ & & \\
\hline 12 & Others & Metronidazole & & $\sqrt{ }$ & Hydrogen Bond \\
\hline & & Metronidazole & Nitro aromatic & - & - \\
\hline & & benzoate & & & \\
\hline & & Vancomycin $\mathrm{HCl}$ & 1. Halogenated Benzene & $\sqrt{ }$ & Hydrogen Bond \\
\hline & & & (nongenotoxic mechanism) & & \\
\hline & & & $\begin{array}{l}\text { 2. o-phenylphenol (nongenotoxic } \\
\text { mechanism) }\end{array}$ & & \\
\hline
\end{tabular}


Information :

$(\sqrt{ }) \quad:$ toxicophores include pharmacophores

(-) : there is no toxicophores include pharmacophores

\section{CONCLUSION}

There were 36 drugs in the class of antibiotics that were potentially carcinogenic and mutagenic properties on the human body because it contains toxicophores that was included in pharmacophores binding to its protein target through hydrogen bonds. It can be used as supporting data for the structure modification of the drug in order to drug discovery.

\section{REFERENCES}

Benigni, R., Bossa, C., Tcheremenskaia, O., and Worth, A., (2009). Development of Structural Alerts for The in vivo Micronucleus Assay in Rodents. EUR 23844 EN.

ChemDraw Ultra. 2013. http://www.cambridgesoft.com/ensemble_for_Chemistry/chemdraw/. Retrieved 7 Juli 2016.

Eisenbrand, G., Pool-Zobel., Baker, V., Balls, M., Blaauboer, B.J., Boobis, A., Carere, A., Kevekordes, S., Lhuguenot, C.J., Pieters, R., and Kleiner, J., (2002). methode of in vitro toxicology. Food and Chemical Toxicology, vol. 40, pp. 193-236.

Ekins, S., Mestres, J., and Testa, B., (2007) . In Silico Pharmacology for Drug Discovery : Methods for Virtual Ligand Screening and Profiling. British Journal of Pharmacology, Volume 152, pp. 9-20.

Fielden, R.M., and Kolaja, L.K., (2008). The role of early in vivo toxicity testing in drug discovery toxicology. Expert OPin. Drug Saf, Vol. 2 No. 7, pp. 107-110.

Lambert, DG., (2004). Drug and Reseptor. Continuing Education in Anaesthesia, Critical Care \& Pain. Vol. 4 No. 34.

Molegro Virtual Docker 5.0, (2011), Molegro Virtual Docker User Manual, http://clcbio.com/wp-content/uploads/2012/09/MVD_Manual.pdf, Retrieved 10 Juli 2016.

Noori, R.H., and Spanagel, R., (2013). In Silico pharmacology: drug design and discovery's gate to the future. Springer Open Journal, Vol. 1 No. 1.

Onkara, P., Kumar, S.A., Kanakaraju, S., Prasanna, B., Pydisetty, Y., and Chandramouli, G.V.P., (2013). Molecular Docking Studies, Synthesis and Anti-Bacterial Properties of New Mannich Bases. International Journal of Pharma and Bio Sciences, Vol. 2 NO. 4, p. 263-270.

Parasurahman, R., (2011). Toxicological Screening. Journal of Pharmacology and Pharmacotherapeutics, Vol. 2, Issue 2.

PubChem. 2004. https://pubchem.ncbi.nlm.nih.gov/about.html, Diakses tanggal 4 September 2016.

Thomsen, R., M.H. Christensen, (2006), MolDock: A New Technique for High-Accuracy Molecular Docking, J. Med. Chem., volume 49, pp. 3315-3321.

Toxtree V.2.6.13., (2015). Joint Research Centre. Institute for Health and Consumer Protection, http://toxtree.sf.net, Retrieved 7 Juli 2016.

Van de Waterbeemd, H., Carter, R.E., Grassy, G., Kubinyi, K., Martin, Y.C., Tute, M.S., Willett, P., (1997). Glossary of Terms Uses in Computational Drug Design (IUPAC Recommendations 1997), P 1137. 